Bangladesh Journal of Anatomy January 2011, Vol. 9 No. 1 pp 26-29

\title{
Incidence of Presence \& Variation in Anatomical Position of Isthmus of Thyroid Gland in Bangladeshi Cadaver
}

\author{
Seheli Zannat Sultana ${ }^{1}$, Mohsin Khalil', Manjurul Karim Khan ${ }^{3}$, Mst.Laila Anjuman Banu ${ }^{4}$, \\ Zubaida Gulshan Ara ${ }^{5}$, Fakhrul Amin Mohammad Hasanul Banna ${ }^{6}$
}

\begin{abstract}
Context: The thyroid gland is the first endocrine organ to evolve in the vertebrates. It has right and left lobes and connected by narrow median isthmus which lies over the second, third and fourth tracheal rings. A conical pyramidal lobe often ascends towards the hyoid bone from isthmus or the adjacent part of either lobe. It measures about $1.25 \mathrm{~cm}$ transversely and vertically. Its size and site vary greatly. Isthmus is topographically related with some important anatomical structures. So this study was carried out to determine the incidence of presence \& variation in anatomical position of isthmus of thyroid gland of Bangladeshi people of different age groups to establish a normal standard.
\end{abstract}

Study type : Descriptive cross-sectional study.

Place and period of study: Department of Anatomy, Mymensingh Medical College.

from October'2004 to February'2005.

Materials: The study was carried out on 60 cadavers of different age groups age ranging from 11 to 70 years. Thyroid glands were collected from unclaimed dead bodies autopsied in Forensic Medicine Department of Mymensingh Medical College.

Methods: The collected specimens were divided into age group A (upto 18 years), group B (18 to 45 years), group C (above45 years). All specimens were examined morphologically by fine dissection method.

Result: In the present study isthmus was present in 41 (68.33\%) cases. In those thyroids which were devoid of isthmus, lobes were found to be merged with each other in the midline but in one case two lobes were found completely separated from each other. It was evident that the posterior relations of isthmus were widely variable. In only $18 \%$ cases it was found at its usual position- against the $2 \mathrm{nd}$, 3rd and 4 th tracheal rings. In the present study more frequent location of isthmus was found at 1st, 2nd, 3rd and 2nd, $3 r d, 4$ th tracheal rings. In both cases their incidences were $18.3 \%$.

Conclusion: The present study will help to increase the information pool on the anatomy of thyroid gland of Bangladeshi people. To establish a normal standard for Bangladeshi people, further studies with large samples from different zones of the country are suggested.

Key Word- Isthmus, Human Thyroid gland, Incidence, Posterior relation, Bangladesh

1. Associate Professor of Anatomy, Mymensingh Medical College, Mymensingh

2. Professor \& Head of The Department of Anatomy, Mymensingh Medical College, Mymensingh

3. Assistant Professor of ENT, Mymensingh Medical College, Mymensingh

4. Associate Professor of Anatomy, BSMMU, Dhaka.

5. Assistant Professor of Anatomy, Community Based Medical College Bangladesh, Mymensingh.

6. Assistant Professor of Anatomy, Addin Womens Medical College, Dhaka.

Correspondence: Dr. Seheli Zannat Sultana

\section{Introduction}

Thyroid gland is a notably labile gland that varies greatly in size and structure ${ }^{1,2}$ \& many diseases affecting thyroid gland are associated with its enlargement and require medical and surgical intervention, estimation of size and appreciation of variational anatomy of each part of thyroid gland including its topographic relationship with adjacent structures is clinically important in the evaluation and management of thyroid disorders ${ }^{3}$. 
The isthmus connects the lobes in the median plane. It measures about $1.25 \mathrm{~cm}$ transversely and vertically, and usually anterior to the $2 \mathrm{nd}$ and $3 \mathrm{rd}$ tracheal cartilages. Its size and site vary greatly. Isthmus is topographically related with some important anatomical structures. Superior thyroid arteries of both side anastomose along its upper border \& at the lower border the inferior thyroid vein leave the gland $d^{2,4,5}$.

As the isthmus of thyroid gland is closely attached by the pretracheal fascia with thyroid cartilage, its swelling shows a well known clinical sign that the thyroid moves upwards on swallowing, by which thyroid swelling may be differentiated from any other neck swellings 6,7 .

The basic reason of positional changes of thyroid isthmus in the developmental period is disproportion between fetus gland \& cervix growth rates. The knowledge of variation of gland position is very important in many specializations, from obstetrician through neonatal pediatrician, neck surgeon to anatomopathologist.

\section{Method}

This cross sectional descriptive study was performed on 60 post mortem human thyroid glands collected from Bangladeshi cadavers of both sexes (male 48 and female12), age ranging from 11 to 70 years. Specimens containing thyroid gland were collected from dead bodies autopsied on different dates from October'2004 to February'2005 at the autopsy laboratory of Forensic Medicine Department of Mymensingh Medical College, Mymensingh. Only fresh specimens from persons who died within the preceding 12 to 24 hours were chosen.

The study was carried out in the Department of Anatomy of Mymensingh Medical College, Mymensingh, from July'2004 to June'2005. For convenience of differentiating the findings regarding incidence in relation to age, the collected specimens were divided into three groups e.g. A, B and C (Table-I).
After fixation in $10 \%$ formal saline solution the anterior aspects of specimen block consisting of the thyroid gland and adjacent related structures were dissected meticulously. Keeping the specimen of the thyroid in the anatomical position, two permanent markings were given in the midline at the upper and lower borders of the isthmus with the help of suture. The markings were applied by perforating the underlying structure (trachea, cricoid cartilage) horizontally before backwards with a long needle and the thread was passed and tied into a knot. Then after removal of the thyroid gland, the area between the two markings was taken as the posterior relation of the isthmus.

\section{Result}

Incidence of isthmus of Thyroid Gland

In the present study isthmus was present in 41 (68.33\%) cases out of 60 cadavers but was absent in 19 (31.66\%) cases. Its incidence in different age groups and sex was shown in Table-II. In those thyroids which were devoid of isthmus, lobes were found to be merged with each other in the midline (Fig. $1 \& 2$ ), but in one case two lobes were found completely separated from each other (Fig. 3).

Table-I

Age Distributions in Different Age Groups of the Present Study

\begin{tabular}{llcc}
\hline Group & $\begin{array}{l}\text { Age limit in } \\
\text { years }\end{array}$ & $\begin{array}{c}\text { No of } \\
\text { specimen (n) }\end{array}$ & $\begin{array}{c}\text { Percentage } \\
(\%)\end{array}$ \\
\hline A & Upto 18 & 14 & 23.33 \\
B & 19 to 45 & 30 & 50 \\
C & Above 45 & 16 & 26.66 \\
\hline Total & 11 to 70 & 60 & 100 \\
\hline
\end{tabular}


Table II

Incidence of Isthmus - in Different Sexes

\begin{tabular}{|c|c|c|c|c|c|c|}
\hline \multirow[t]{2}{*}{ Sex } & \multicolumn{2}{|c|}{ Present } & \multicolumn{3}{|c|}{ Absent } & \multirow[t]{2}{*}{ Total } \\
\hline & Number (n) & Percent (\%) & Number (n) & \multicolumn{2}{|c|}{ Percent (\%) } & \\
\hline Male & 30 & 62.5 & 18 & \multicolumn{2}{|c|}{37.5} & 48 \\
\hline Female & 11 & 91.66 & 1 & \multicolumn{2}{|c|}{8.3} & 12 \\
\hline \multirow[t]{4}{*}{$\overline{\text { Total }}$} & 41 & 68.3 & 19 & & 66 & 60 \\
\hline & \multicolumn{5}{|c|}{ Incidence of Isthmus - in different age group } & \\
\hline & \multicolumn{2}{|c|}{ Group A } & \multicolumn{2}{|c|}{ Group B } & \multicolumn{2}{|c|}{ Group C } \\
\hline & Number & Percent (\%) & Number & Percent (\%) & Number & Percent (\%) \\
\hline Present & 12 & 85.7 & 18 & 60 & 11 & 88.75 \\
\hline Absent & 02 & 14.28 & 12 & 40 & 05 & 31.25 \\
\hline
\end{tabular}

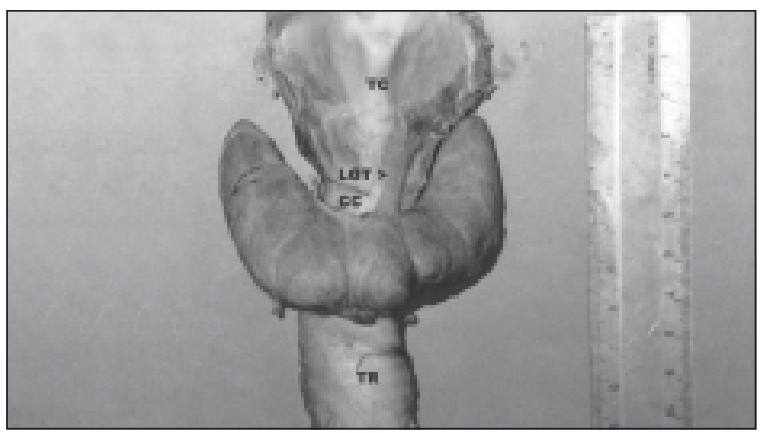

Fig.-1. Photograph of thyroid gland having no isthmus, showing the levator glandulae thyroideae cranially attached with left oblique line of thyroid cartilage (TC). Here TR indicates trachea \& CC indicates cricoid cartilage.

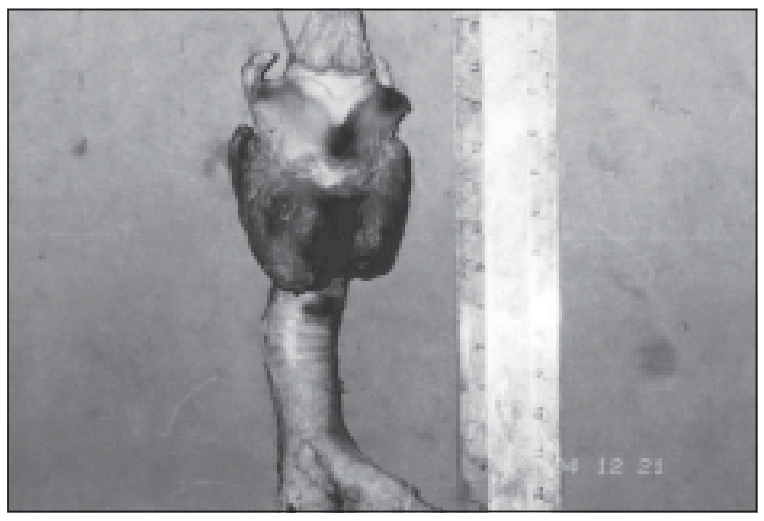

Fig.-2. Photograph of thyroid gland devoid of isthmus. Here unequal sized right (larger) and left lobes were found to be merged with each other in the midline.

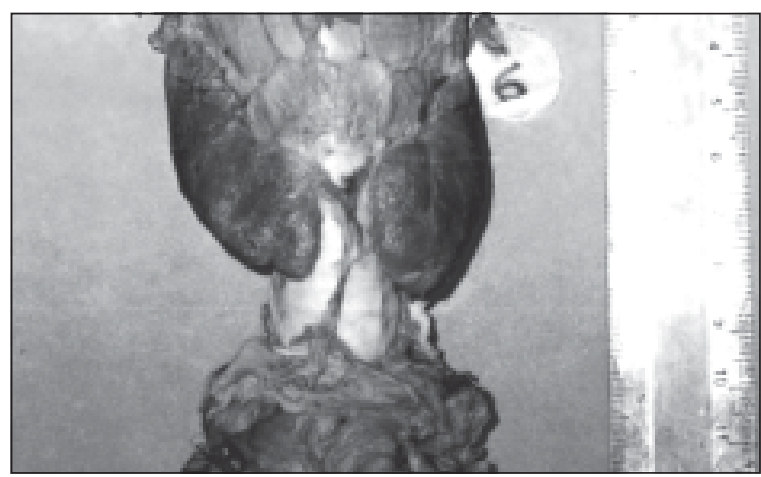

Fig.-3. Photograph of thyroid gland showing absence of isthmus and completely detached right and left lobe.

\section{Posterior Relation of Isthmus}

In this study thyroid isthmus was found to occupy a variable position, extending from cricoid cartilage upto 6th tracheal ring. The incidence of posterior relations with different structure was also shown in Table-III. In the present study more frequent location of isthmus was found at 1st, 2nd, 3rd and 2nd, 3rd, 4th tracheal rings. In both cases their incidences were $18.3 \%$. 
Table-III

Posterior Relations of the Isthmus

\begin{tabular}{lcc}
\hline Related structure & Frequency & Percent \% \\
\hline Cricoid cartilage and & 01 & 1.7 \\
1st tracheal ring & & \\
1st and 2nd ring & 06 & 10.0 \\
1st, 2nd and 3rd ring & 11 & 18.3 \\
1st, 2nd, 3rd and 4th ring & 01 & 1.7 \\
1st, 2nd, 3rd, 4th and 5th ring & 01 & 1.7 \\
2nd and 3rd ring & 06 & 10.0 \\
2nd, 3rd and 4th ring & 11 & 18.3 \\
2nd to 6th ring & 01 & 1.7 \\
3rd and 4th ring & 03 & 5.0 \\
Present in total & 41 & 68.3 \\
\hline
\end{tabular}

\section{Discussion}

Isthmus of the thyroid gland is the constricted part which connects the thyroid lobes in the median plane $^{8}$. The size and site of this structure vary greatly and sometimes may be absent ${ }^{8}$. Marshall and Enayetullah observed such phenomenon in 10\% and $4 \%$ cases respectively. But Begum observed isthmus in all cases of her study, 5,10.

In the present study isthmus was absent in $31.7 \%$ cases. This incidence was much higher than those of previous studies done by Marshall ${ }^{11}$ and Enayetullah $^{9}$, where such phenomenon was observed in only $10 \%$ and $4 \%$ cases respectively. Most of the textbooks agreed that, the isthmus may be absent but did not mention incidence of occurrence of such phenomenon.

Regarding site of the isthmus, Enayetullah ${ }^{7}$ observed that in most cases (72\%) it was related posteriorly to the 2nd to 4th rings of trachea. Begum $^{10}$ found that isthmus of the thyroid gland was related posteriorly to the $2 \mathrm{nd}$, 3rd and 4 th ring of trachea in about $71.67 \%$ cases and in $26.77 \%$ cases isthmus lies against $2 \mathrm{nd}$, 3rd, 4th and 5th tracheal rings.

In the present study, posterior relation of isthmus was very much variable. Thyroid isthmus was found to occupy a variable position, extending from cricoid cartilage upto 6th tracheal ring. But larger percentage of isthmus was found against the 1st, 2nd, 3rd (18.3\% cases) and 2nd, 3rd, 4th (18.3\% cases) tracheal rings which agreed with those of the Enayetullah ${ }^{9}$, Begum $^{10}$ and Berkovitz ${ }^{5}$, although observation of present study was found to be much lower than those described by them.

This wide variability regarding position of the isthmus may be explained by failure of descent or excessive descent of thyroid gland during its embryonic course.

\section{References}

1. Arey LB. Human histology. 4th ed. Philadelphia: W. B. Saunders; 1974. 171-5.

2. Kelly DE, Wood RL, Andes AC, editors. Bailey's textbook of microscopic anatomy. 18th ed. Baltimore: Williams and Wilkins; 1984.794-804.

3. Walker BR, Toft AD. Endocrine disease. In: Hastett C, Chilvers ER, Boon NA, Colledge NR, Hunter JAA. Davidson's principles and practice of medicine.19th ed. Edinburgh: Churchill Livingstone; 2004. 689-704.

4. Leeson TS, Leeson CR, Paparo AA. Text and atlas of histology. 1st ed. Philadelphia: WB Saunders; 1988. 579-86.

5. Berkovitz BK, editor. Neck and upper aerodigestive tract. In: Standring S, Ellis H, Healy JC, Johnson D, Williams A, Collins P, Wigley $C$, editors. Gray's anatomy: the anatomical basis of clinical practice. 39th ed. Edinburgh: Elsevier Churchill Livingstone; 2005. 560-4.

6. Chatterjee CC. Human physiology (vol-2).10th ed. Calcutta: Medical Allied Agency; 1994. 465\%4-69.

7. Swash M. Hutchison's clinical methods. 21st ed. Edinburgh: W. B. Saunders; 2002. 327.

8. Sinnatamby CS, editor. Last's anatomy: regional and applied. 10th ed. Edinburgh: Churchill Livingstone; 2006. 26, 351-3.

9. Enayetullah M. Gross and histomorphological study of the thyroid gland and parathyroid glands in Bangladeshi people (M. Phil. thesis). Dhaka: University of Dhaka; 1996.

10. Begum M. Gross and histomorphological study of human postmortem thyroid gland in Bangladeshi people (M.phil thesis). Dhaka: University of Dhaka; 2004.

11. Marshall CF. Variations in the form of the thyroid gland in man. J. Anat and Physiol 1995; 29: 234-9. 